\title{
Serum estradiol level and postmenopausal symptoms in surgical and natural menopause
}

\author{
Navdeep Kaur*, Veena G. Malla, Sonal Gupta
}

Department of Obstetrics and Gynecology, PGIMER, Dr Ram Manohar Lohia Hospital, New Delhi, India

Received: 24 June 2017

Accepted: 24 July 2017

\section{*Correspondence:}

Dr. Navdeep Kaur,

E-mail: navdeepsandhu108@gmail.com

Copyright: (C) the author(s), publisher and licensee Medip Academy. This is an open-access article distributed under the terms of the Creative Commons Attribution Non-Commercial License, which permits unrestricted non-commercial use, distribution, and reproduction in any medium, provided the original work is properly cited.

\begin{abstract}
Background: Menopause whether it occurs naturally or surgically is characterized by the reduced production of hormones by the ovaries. The study aimed at comparing the serum estradiol levels and postmenopausal symptoms in women with surgical and natural menopause.

Methods: 50 women each of natural and surgical menopause were enrolled. Five ml of fasting blood sample was collected from each patient in both the groups by venepuncture in a plain tube, which was centrifuged and was analyzed for serum estradiol levels by chemiluminescence method. Levels of serum estradiol hormone for both the groups were compiled and the mean and standard deviation was calculated. Postmenopausal symptoms were also compared among two groups. Chi square and fisher exact test were used to analyze the qualitative data and t test were used to analyze the quantitative data.

Results: The mean level of serum estradiol in women with surgical menopause was found to be $20.49+3.16 \mathrm{pg} / \mathrm{ml}$ while that in natural menopause, was $27.41+5.08 \mathrm{pg} / \mathrm{ml}$. The difference in mean estradiol level between the two groups was found to be statistically significant ( $\mathrm{p}$ value $<0.0001$ ). Hot flushes and mood swings were observed in more number of women with surgical menopause.

Conclusions: The statistically significant lower levels of serum estradiol in surgical menopausal group may be a reason behind increased presence of menopausal symptoms in this group. Thus, the women in this group may benefit from hormone replacement therapy, improving their quality of life, however further studies are needed to establish this role.
\end{abstract}

Keywords: Natural menopause, Postmenopausal symptoms, Serum estradiol, Surgical menopause

\section{INTRODUCTION}

Menopause is a universal and irreversible part of the overall aging process. The number of postmenopausal women are increasing worldwide (more than 1.1 billion are expected by 2025), and these women are surviving longer than their predecessors. ${ }^{1}$ The average life expectancy of women in developed countries is projected to increase from 79-82 yrs. ${ }^{1}$ Women are facing longer periods of menopause approximately a third of their life. According to Indian Menopause Society research, the average age of Indian menopausal women is 47.5 years. $^{2}$ The ovary is a dynamic organ of female reproductive life and it undergoes functional and morphological changes during lifetime. During the reproductive years, the ovaries are the principle source of estradiol that acts on distal target tissues to maintain normal menstrual cycle. Estrogen is also produced in a number of extragonadal sites e.g. mesenchymal cells of adipose tissue, osteoblasts and chondrocytes of bone, the vascular endothelium and the aortic smooth muscle cells and numerous sites in brain. $^{3}$ There is $66 \%$ reduction in estrogen levels at 
menopause. ${ }^{4}$ While reduction in estradiol level is gradual in women with natural menopause, there is sudden cessation of this hormone in surgical menopause. Various postmenopausal symptoms like hot flushes, vaginal dryness and psychological symptoms are experienced by over $70 \%$ of postmenopausal women due to decrease in estradiol levels affecting quality of life of women but these are more severe and abrupt in surgical menopause. ${ }^{5}$ Estrogen also protects from various chronic conditions like coronary heart disease and osteoporosis. Although the natural menopause is diagnosed after 12 months resulting from loss of ovarian follicular activity yet the ovaries continue to produce significant amount of androgens (about $25 \%$ of testosterone) as long as 10 years beyond menopause which are converted to estrogen in the extragonadal sites mainly adipose tissue by enzyme aromatase. $^{6,7}$ Surgical menopause results from sudden cessation of menses after surgical removal of uterus alone or removal of one or both ovaries experiencing early menopause. ${ }^{8}$ Hormone replacement therapy might be an option for women with surgical menopause.

\section{METHODS}

This study was a cross sectional prospective observational study and was conducted in the gynecology department of PGIMER, Dr. Ram Manohar Lohia Hospital, New Delhi after getting clearance from hospital ethical committee. Study duration was from November 2014 to March 2016 and included 50 women each belonging to surgical menopause (group I) and natural menopause (group II). Women enrolled in both the groups were 1-2 yrs postmenopausal with BMI of 18.5$25 \mathrm{~kg} / \mathrm{m} 2$ and aged 44-52 years. Women in whom hysterectomy was done for malignant causes, those on hormonal replacement therapy and steroids were excluded. After obtaining written informed consent from each patient, a detailed history including type and duration of menopause was noted. Various postmenopausal symptoms with detail of each symptom were obtained by questionnaire method. History of any chronic medical illness, personal history and drug history was noted. A complete general and gynecological examination was done. Five $\mathrm{ml}$ of blood sample was collected from each patient in both the groups by venepuncture in a plain tube and was centrifuged. Serum estradiol levels were measured in all the samples in both group I and group II by chemiluminescence method in the biochemistry lab of Dr Ram Manohar Lohia hospital. Primary outcome was to compare the serum estradiol levels between groups I and II. Secondary outcome was to determine the presence and time of onset of all the postmenopausal symptoms.

A statistical analysis was performed by using SPSS 16 and Graph pad Prism software. Chi square and fisher exact test were used to analyze the qualitative data and $t$ test were used to analyze the quantitative data. A $p$ value of $<0.05$ was considered to be statistically significant.

\section{RESULTS}

The present study included 50 women with surgical menopause (Group I) and 50 women with natural menopause (Group II). A total of 100 subjects fulfilling the inclusion criteria were enrolled in this study. The mean age of women enrolled, age and duration of menopause, and BMI were comparable in both the groups (Table 1).

Table 1: Patient descriptive data in group I and group II.

\begin{tabular}{|lll|}
\hline Variable (years) & $\begin{array}{l}\text { Group I } \\
(\mathrm{n}=50)\end{array}$ & $\begin{array}{l}\text { Group II } \\
(\mathrm{n}=50)\end{array}$ \\
\hline Mean age & $47.46 \pm 2.61$ & $48.42 \pm 2.60$ \\
\hline Mean age at menopause & $46.06 \pm 2.58$ & $46.84 \pm 2.39$ \\
\hline $\begin{array}{l}\text { Mean duration of } \\
\text { menopause }\end{array}$ & 1.40 & 1.58 \\
\hline Mean BMI $\left(\mathrm{Kg} / \mathrm{m}^{2}\right)$ & $22.95 \pm 1.65$ & $23.02 \pm 1.45$ \\
\hline
\end{tabular}

The mean level of serum estradiol hormone in group I was found to be $20.49+3.16 \mathrm{pg} / \mathrm{ml}$ while that in natural menopause was, $27.41+5.08 \mathrm{pg} / \mathrm{ml}$. The level of estradiol measured were lower in surgical menopausal women as compared to natural menopausal women and this difference was found to be statistically significant ( $p$ value $<0.0001$ ) (Table 2).

Table 2: Mean serum estradiol levels in natural and surgical menopausal women.

\begin{tabular}{|c|c|c|c|c|}
\hline Menopause & $\mathbf{N}$ & $\begin{array}{l}\text { Mean E2 } \\
(\mathrm{pg} / \mathrm{ml})\end{array}$ & $\begin{array}{l}\text { Standard } \\
\text { deviation } \\
(\mathrm{pg} / \mathrm{ml})\end{array}$ & $P$ value \\
\hline $\begin{array}{l}\text { Surgical } \\
\text { (group I) }\end{array}$ & 50 & 20.49 & 3.16 & \multirow{2}{*}{$<0.0001$} \\
\hline $\begin{array}{l}\text { Natural } \\
\text { (group II) }\end{array}$ & 50 & 27.41 & 5.08 & \\
\hline
\end{tabular}

Table 3: Comparison of postmenopausal symptoms between two groups.

\begin{tabular}{|c|c|c|c|}
\hline Symptoms & $\begin{array}{l}\text { Group } \\
I(n=50)\end{array}$ & $\begin{array}{l}\text { Group } \\
\text { II(n=50) }\end{array}$ & $\begin{array}{l}P \\
\text { value }\end{array}$ \\
\hline Hot flushes & $34(68 \%)$ & $23(46 \%)$ & 0.02 \\
\hline $\begin{array}{l}\text { Vaginal dryness and } \\
\text { pruritus }\end{array}$ & $23(46 \%)$ & $20(40 \%)$ & 0.54 \\
\hline Dyspareunia & $17(34 \%)$ & $9(18 \%)$ & 0.06 \\
\hline Dysuria & $21(42 \%)$ & $19(38 \%)$ & 0.68 \\
\hline Urinary incontinence & $16(32 \%)$ & $11(22 \%)$ & 0.26 \\
\hline Mood swings & $24(48 \%)$ & $14(28 \%)$ & 0.03 \\
\hline $\begin{array}{l}\text { Cognitive aging and } \\
\text { dementia }\end{array}$ & $22(44 \%)$ & $15(30 \%)$ & 0.14 \\
\hline
\end{tabular}

Postmenopausal symptoms were experienced by a higher number of women in surgical menopause group. Among the various postmenopausal symptoms, hot flushes were found to be the predominant symptom experienced by 
women in both the groups. Hot flushes and mood swings were observed more frequently in women with surgical menopause as compared to women in natural menopause group and this difference was found to be statistically significant. The other symptoms noted in the two groups were dyspareunia, dysuria, urinary incontinence and cognitive changes but the difference was not statistically significant between the two groups (Table 3 ).

It was also observed that the postmenopausal symptoms appeared earlier in women with surgical menopause when compared to women with natural menopause (Table 4).

Table 4: Time of onset of post-menopausal symptoms.

\begin{tabular}{|lll|}
\hline & \multicolumn{2}{l|}{ Onset of symptoms (years) } \\
\hline Symptoms & Group I & Group II \\
\hline Hot flushes & $0.73 \pm 0.41$ & $0.95 \pm 0.38$ \\
\hline $\begin{array}{l}\text { Vaginal dryness and } \\
\text { pruritus }\end{array}$ & $0.96+0.28$ & $1.20+0.27$ \\
\hline Dyspareunia & $0.91+0.29$ & $1.31+0.38$ \\
\hline Dysuria & $1.00+0.21$ & $1.15+0.36$ \\
\hline Incontinance & $1.07+0.27$ & $1.03+0.26$ \\
\hline Mood swings & $0.87+0.31$ & $1.00+0.17$ \\
\hline $\begin{array}{l}\text { Cognition and } \\
\text { dementia }\end{array}$ & $1.13+0.28$ & $1.46+0.39$ \\
\hline
\end{tabular}

In the current study, it was also noted that the lower levels of serum estradiol in surgical menopausal group was associated with higher frequency of postmenopausal symptoms like hot flushes and mood swings when compared to natural menopausal group.

\section{DISCUSSION}

Menopause has been considered as a crucial step in a woman's life and its effect are more pronounced following surgical menopause due to rapid decline in estrogen levels. Statistically significant lowered levels of serum estradiol were observed in women with surgical menopause as compared to natural menopause in the current study. Farhana Kabir et al have also noted similar results with lower levels of serum estradiol in surgical menopausal group $(16.73 \mathrm{pg} / \mathrm{ml})$ when compared to natural menopausal group $(26.57 \mathrm{pg} / \mathrm{ml}) .{ }^{9}$ Naik R et al have observed similar results with the mean level of estradiol level in surgical and natural menopausal group to be $10.72 \pm 2.30 \mathrm{pg} / \mathrm{ml}$ and $18.18 \pm 2.59 \mathrm{pg} / \mathrm{ml}$ respectively and this difference was found to be statistically significant ( $\mathrm{p}$ value $<0.001$ ). ${ }^{5}$ Furuhashi $\mathrm{N}$ et al have also reported similar results. ${ }^{10}$

Several studies have observed presence of postmenopausal symptoms following natural menopause but very few studies have compared various postmenopausal symptoms between surgical and natural menopause like the current study. The percentage of surgical menopausal women experiencing hot flushes and mood swings was significantly higher than that of natural menopausal women in the present study. Pearce $\mathbf{J}$ et al and Bachmann GA et al reported similar significant difference in hot flushes percentage between two menopausal groups and concluded that hot flushes tend to last longer and be more severe in women who have had a surgically induced menopause. ${ }^{11,12}$ Nachtigall et al 30 reported that $100 \%$ of surgically menopausal women had vasomotor symptoms, and $90 \%$ had severe symptoms which lasted an average of 8.5 years after menopause. ${ }^{13}$

Naik R et al have also observed higher frequency of hot flushes and mood swings in women with surgical menopause when compared to natural menopause however genitourinary symptoms were also experienced by a higher number of women with surgical menopause unlike present study. ${ }^{14}$ Dyspareunia, dysuria, urinary incontinence and memory changes were some of the other symptoms, present in both the groups but the difference was not statistically significant. Postmenopausal symptoms appeared earlier in surgical menopausal group in comparison to natural menopause.

Women with surgical menopause were found to have lower levels of serum estradiol and experienced bothersome postmenopausal symptoms as compared to natural menopause. Thus, hormone replacement therapy may be an effective option for ameliorating these in appropriately selected cases.

\section{ACKNOWLEDGMENTS}

Authors would like to thank he department of Obstetrics and Gynecology, department of Biochemistry, PGIMER Dr RML Hospital New Delhi and the study subjects for their co-operation and support.

Funding: No funding sources

Conflict of interest: None declared

Ethical approval: The study was approved by the Institutional Ethics Committee

\section{REFERENCES}

1. Appt SE, Clarkson TB, Hoyer PB, Kock ND, Goode $\mathrm{AK}$, May $\mathrm{MC}$ et al. Experimental induction of reduced ovarian reserve in a non-human primate model. Comp Med. 2010;60(5):380-8.

2. Pal A, Hande D, Khatri S. Assessment of menopausal symptoms in perimenopause and post menopause women above 40 years in rural area. Internat J Healthc Biomedic Res. 2013;1(3):166-74.

3. Simpson ER. Sources of estrogen and their importance. J steroid Biochem Molecul Biol. 2003;86:225-30.

4. Padubidri VG, Daftary SN. Perimenopause, Menopause, Premature menopause and Postmenopausal bleeding. Howkins and Bourne Shaw's textbook of Gynecology. $15^{\text {th }}$ ed. New Delhi: Elsevier India Pvt Ltd; 2011:62. 
5. Naik R, Chandel Rittu S, Abichandani LG. Comparison of serum estradiol levels in surgical and natural menopause. IOSR. 2014;9(1):65-67.

6. Menopause Terminology. Indian Menopause Society. WHO, 2015. Available from: www.imsociety.org/menopause_terminology.php\#.A ccessed 6 april2016

7. Fogle R, Stanczyk FZ, Zhang X, Paulson RJ. Ovarian androgen production in postmenopausal women. JCEM. 2013;92(8):3040-43.

8. Kate MB. Can hysterectomy be considered a risk factor for cardiovascular disease. Circulation. Journal of American heart association. 2005;111:1456-8.

9. Kabir F, Jahan N, Sultana N, Akter R. Lipid profile status in surgical menopause. J Bangladesh Soc Physiol. 2011;6(2):127-33

10. Furuhashi N, Abe T, Suzuki M. Changes in Hypophysio-ovarian Endocrinological Function of Post-menopausal and Surgical menopausal women In Tohoku J Med. 1976;120;19-24.

11. Pearce J, Hawton K, Blake F. Psychological and sexual symptoms associated with the menopause and the effects of hormone replacement therapy. $\mathrm{Br} \mathrm{J}$ Psych. 1995;167:163-73.

12. Bachmann GA. Vasomotor flush in menopausal women. Am J Obstet Gynecol. 1999;180:S312-6.

13. Nachtigall LE. Preoperative care and patient evaluation. Proceedings of the 1996 annual meeting of the American College of Obstetricians and Gynaecologists; 1996.

14. Naik R, ChandelRittu S, Abichandani LG. Comparative study of gonadotropin levels and clinical presentation in surgical and natural menopause. Internat J Medic Res Health Sci. 2014;3(1):149-54.

Cite this article as: Kaur N, Malla VG, Gupta S. Serum estradiol level and postmenopausal symptoms in surgical and natural menopause. Int J Reprod Contracept Obstet Gynecol 2017;6:3920-3. 